\title{
Injuries in high-skilled and low-skilled soccer: a prospective study
}

\author{
T.D. Poulsen MD, K.G. Freund MD, F. Madsen MD and K. Sandvej MD \\ Department of Orthopaedic Surgery, Esbjerg Central Hospital, Denmark
}

Fifty-five male soccer players organized in three teams, one high and two lower ranking, were followed prospectively during 1 year to register the rate, type and severity of injuries in highly skilled and low-skilled players.

The injury rate of the low-skilled players was significantly higher than that of the better players. The reason for this is that low-skilled players play in more competitions and this is where injuries tend to occur. When we stratified on game/practice, the low-skilled players' excess risk disappeared and no difference was found in the severity of injuries.

Different ways of collecting data in epidemiological studies of soccer are discussed and it is concluded that the most precise and accurate collection of data can only be obtained by direct supervision and examination of soccer players in the field.

Keywords: Sports injuries, soccer, rate, epidemiology

Soccer is universally popular and the most widespread sport in the world ${ }^{1-3}$. Being a contact sport it leads to a relatively high incidence of injuries, and recently there has been increasing interest in analysing the epidemiological and traumatological pattern of soccer injuries.

There have been some discrepancies in the reported frequencies and types of injuries ${ }^{1}$, which might be a consequence of different ways of obtaining information. To achieve optimal data collection we therefore designed this study as a prospective register of injuries, recorded by direct supervision in the field; the primary aim was to detect possible differences in the injury rate, type and severity in high-skilled and low-skilled soccer players.

\section{Material and methods}

In Denmark male soccer is organized by the Danish Football Association (DBU) with approximately 150

Address for correspondence: Torben Dam Poulsen MD,

Havbakken 196, DK 6710 Esbjerg V, Denmark

(C) 1991 Butterworth-Heinemann Ltd.

0306-3674/91/030151-03 clubs and 100000 licensed registered senior players. The senior league system is organized in 11 levels, the highest being Division I and the lowest being Serie 6 .

The study was designed as a cohort study. During the tournament year of 1986 we followed three teams comprising 55 players: one top team playing in Division I (group A) and two lower ranking teams playing in Serie 3 and 5, respectively (group B) (Table 1 ). Each player was asked about his active years playing soccer.

During the year the practice and the game time was recorded (Table 2), and personal consultations were made by the authors once or twice a week to register any injury occurring during scheduled games or practices which caused the player to miss the next game or practice session ${ }^{2}$.

The statistical tests used were the Mann-Whitney test, when comparing data on an ordinal scale, and the $\chi^{2}$ test with stratification ${ }^{4}$ using the Mantel-Haenzel test. The level of statistical significance was $P<0.05$.

Table 1. Age and experience distribution (medians and first to third quartiles)

\begin{tabular}{lccc}
\hline & $\begin{array}{c}\text { No. of } \\
\text { players }\end{array}$ & $\begin{array}{c}\text { Age* } \\
\text { (years) }\end{array}$ & $\begin{array}{c}\text { Years playing } \\
\text { soccert }\end{array}$ \\
\hline Group A & 19 & $24(21-28)$ & $18(13-24)$ \\
Group B & 36 & $27(24-30)$ & $14(11-16)$ \\
\hline
\end{tabular}

* Not significant; + significant

Table 2. Time of exposure (medians and first to third quartiles)

\begin{tabular}{lcc}
\hline & Game hours* & Practice hourst \\
\hline Group A & $41(20-58)$ & $191(108-244)$ \\
Group B & $28(23-34)$ & $33(16-48)$ \\
\hline
\end{tabular}

* Not significant; + significant 


\section{Results}

A total of 57 injuries was recorded, and an overall injury rate of each group was calculated (Table 3 ). The relative risk for injuries in group B (low-skilled players) was $1.81(P=0.02)$, but this excess risk is primarily because the low-skilled players in group B have more game hours than group $A$, and that the injury rate during games is four times that of practice. When we stratified at game/practice the difference in injury rate between groups $B$ and A nearly disappeared (Table 4) and the Mantel-Haenzel adjusted relative risk for injuries in group $B$ became $1.16(P=$ 0.60).

Analysis of injury rates for both groups related to age and experience showed no statistically significant difference: $36(63 \%)$ of the injuries were game injuries, while $21(37 \%)$ were sustained during practice. Two-thirds (37) of all injuries were single injuries without any opponent being involved.

The severity of injuries is shown in Table 5 in terms of absence from the game after the injury ${ }^{2}$.

Table 3. Non-stratified injury rate

\begin{tabular}{lccc}
\hline & $\begin{array}{c}\text { No. of } \\
\text { injuries }\end{array}$ & $\begin{array}{c}\text { Time of } \\
\text { exposure }(h)\end{array}$ & $\begin{array}{c}\text { No. of injuries } \\
\text { per 1000 } h^{*}\end{array}$ \\
\hline Group A & 29 & 4199 & 6.91 \\
Group B & 28 & 2246 & 12.47 \\
\hline
\end{tabular}

* Significant

Table 4. Stratified injury rates (Mantel-Haenzel test)

\begin{tabular}{lccc}
\hline & $\begin{array}{c}\text { No. of } \\
\text { injuries }\end{array}$ & $\begin{array}{c}\text { Time of } \\
\text { exposure }(h)\end{array}$ & $\begin{array}{c}\text { No. of injuries } \\
\text { per 1000 } h\end{array}$ \\
\hline Game* $^{*}$ & & & \\
Group A & 15 & 759 & 19.76 \\
Group B & 21 & 1015 & 20.69 \\
Practice* & & & \\
Group A & 14 & 3440 & 4.07 \\
Group B & 7 & 1231 & 5.69 \\
\hline
\end{tabular}

* The difference between Group A and B is not significant

After stratification on type of play (game/practice), the relative risk of injuries in Group B is 1.16; there is thus no significant difference between Group $A$ and $B\left(\chi^{2}=0.27, P=0.60\right)$.
The location and type of injuries are shown in Table 6. Of the 57 injuries, $54(95 \%)$ were sited in the lower extremities with foot/ankle and knee injuries being the major groups of injuries, 40 and $22 \%$ respectively. There were $37(65 \%)$ traumatic injuries, while the remaining 20 were over-use injuries ( 15 of these were strains of groin or thigh muscle).

\section{Discussion}

Keller et al. reviewed six major studies of soccer epidemiology and prosposed guidelines for future studies ${ }^{1}$.

We find that the most critical point in soccer injury studies is the data collection system. A number of different ways have been used to obtain information: (1) attendance at emergency departments ${ }^{3,5}$ or special sports injury clinics ${ }^{6,7}$; (2) from insurance claims reports $^{8,9} ;$ (3) questionnaires ${ }^{10}$.

The injury rates that we found correspond to the findings of Ekstrand ${ }^{2}$ of a practice injury rate of 7.6 per $1000 \mathrm{~h}$ and a game injury rate of 16.9 .

Registrations from an emergency department ${ }^{3}$ revealed a game injury rate of only 2.2 per $1000 \mathrm{~h}$, while the questionnaire performed by Weightman and Browne ${ }^{10}$ showed an injury rate of 3.65 per $1000 \mathrm{~h}$ without specification of whether the injuries were sustained during practice or game. As expected, these findings underestimate the rate of injury as a consequence of the selective data collection.

In our study, the lower ranking players had a higher overall injury rate than players with higher

Table 5. Severity of injuries

\begin{tabular}{|c|c|c|c|c|}
\hline & Minor & Moderate & Major & Total \\
\hline & No. (\%) & No. (\%) & No. (\%) & No. (\%) \\
\hline $\begin{array}{l}\text { Group A } \\
\text { Group B }\end{array}$ & $\begin{array}{l}7(24) \\
9(32)\end{array}$ & $\begin{array}{l}17(59) \\
14(50)\end{array}$ & $\begin{array}{l}5(17) \\
5(18)\end{array}$ & $\begin{array}{l}29(51) \\
28(49)\end{array}$ \\
\hline Total & $16(28)$ & 31 (54) & 10 (18) & $57(100)$ \\
\hline
\end{tabular}

$\chi^{2}=0.52 ;$ d.f. $=2 ; P=0.77$

The degrees of severity are defined as follows ${ }^{2}$ :

Minor: No absence from game

Moderate: Absence from at least one, but less than, five games

Major: Absence from more than four games

Table 6. Type and location of injuries

\begin{tabular}{|c|c|c|c|c|c|c|c|c|}
\hline \multirow[t]{2}{*}{ Type } & \multicolumn{7}{|c|}{ Location } & \multirow[t]{2}{*}{ Total } \\
\hline & Foot & Ankle & Leg & Knee & Thigh & Groin & Other & \\
\hline \multirow{5}{*}{$\begin{array}{l}\text { Contusion } \\
\text { Vulnus } \\
\text { Sprain } \\
\text { Dislocation } \\
\text { Fracture } \\
\text { Strain } \\
\text { Other }\end{array}$} & $\begin{array}{l}5 \\
2\end{array}$ & & 1 & & 1 & & & 7 \\
\hline & & 10 & & 13 & & & 1 & $\begin{array}{r}2 \\
24\end{array}$ \\
\hline & 3 & 1 & & & & & & $\begin{array}{l}0 \\
4\end{array}$ \\
\hline & 2 & & & & 9 & 6 & & $\begin{array}{r}4 \\
17\end{array}$ \\
\hline & & & & & & & 3 & 3 \\
\hline Total & 12 & 11 & 1 & 13 & 10 & 6 & 4 & 57 \\
\hline
\end{tabular}

The four injuries listed under 'Other' were: two cases of broken teeth, one of a fingersprain and a case of low back pain 
rank, but this apparent difference disappears when a stratified analysis, taking account of the uneven distribution of game/practice time, is carried out.

There have been contradictory reports concerning the injury rates in top level and lower level players. Sandelin et al. ${ }^{8}$ and Roaas and Nilsson' 9 found more injuries in the higher ranking teams, while Peterson and Renström ${ }^{11}$ found no difference in the rates of injury between the players of the different divisions. Weightman and Browne ${ }^{10}$ found fewer injuries in professional players than in amateurs. We find that these discrepancies are a consequence of different ways of obtaining data rather than a reflection of a true relationship. A precise and accurate collection of data can only be obtained by direct supervision and examination of players in the field $2,12,13$.

Absence from the game is a more reliable parameter concerning the severity of injuries than absence from practice, as the top players, when injured, more often than lower ranking players, attend the training sessions to perform modified exercises to keep in shape. According to this, no difference in the severity of injuries between the higher and lower ranking teams was found, though it should be noted that the five players from group A with major injuries were unable to participate in games for 6, 9, 13, 14 and 23 games respectively, while the five players from group $B$ with major injuries were absent from five to eight games. Weightman and Browne ${ }^{10}$ found fewer, but more serious, injuries in professionals than in amateurs. The findings of Roaas and Nilsson ${ }^{9}$, in their insurance study of a higher injury rate in top teams, may reflect that injuries do not necessarily happen more often in higher ranking teams but that they may be more serious, as it must be assumed that the probability of an injury becoming an insurance matter rises proportionately with its seriousness.

The size of study does not permit splitting it further for a more detailed analysis concerning the circumstances under which the injury happened; yet it allows us to conclude that in order to reduce the overall incidence of soccer injuries, attention must be drawn to the lower ranking teams, which comprise the bulk of the world's soccer players. Often these players perform their games and practices under insufficient supervision, on poor playing fields and with a minimum of knowledge of sports physiology and the proper care of injuries.

Correcting these conditions is a task for the national and international football associations - and the physicians who have an interest in sports medicine. Ekstrand showed in 1982 that intervention does have an astonishing effect in reducing injuries.

\section{Acknowledgements}

This study has been subsidized by The Danish Medical Scientific Research Council. Statistical advice was given by Assistant Professor Sven Sabroe MD, Department of Social Medicine, University of Aarhus, Denmark.

\section{References}

1 Keller CS, Noyes FR, Buncher CR. The medical aspects of soccer injury epidemiology. Am I Sports Med 1987; 15: 230-7.

2 Ekstrand J. Soccer and their Prevention. Medical Dissertations No. 130; Linköping University, 1982.

3 Maehlum S, Daljord OA. Football injuries in Oslo: a one-year study. Br J Sports Med 1984; 18: 186-90.

4 Breslow NE, Day NE. Statistical Methods in Cancer Research. Vol. II: The Design and Analysis of Cohort Studies. Lyon: International Agency for Research on Cancer, 1987.

5 Sadat-Ali $M$, Sankaran-Kutty $M$. Soccer injuries in Saudi Arabia. Am J Sports Med 1987; 15: 500-502.

6 Nilsson S, Roaas A. Soccer injuries in adolescents. Am J Sports Med 1978; 6: 358-61.

7 Sullivan JA, Gross RH, Grana WA, Garcia-Moral CA. Evaluation of injuries in youth soccer. Am J Sports Med 1980; 8: 325-7.

8 Sandelin J, Santavirta S, Kiviluoto O. Acute soccer injuries in Finland in 1980. Br J Sports Med 1985; 19: 30-33.

9 Roaas A, Nilsson S. Major injuries in Norwegian football. $\mathrm{Br} J$ Sports Med 1979; 13: 3-5.

10 Weightman D, Browne RC. Injuries in association and rugby football. Br J Sports Med 1984; 8: 183-7.

11 Peterson L, Renström L. Soccer injuries - frequency and type. Läkartidningen 1980; 77: 3621-3.

12 McMaster WC, Waller M. Injuries in soccer Am J Sports Med 1978; 6: 354-7.

13 Albert M. Descriptive three year study of outdoor and indoor professional soccer injuries. Athletic Training 1983; 18: 218-20. 